УДК: $355.433 .4(477)$

Василь Васильович Стасюк (доктор психологічни наук, професор)

Михайло Миколайович Бочаров (кандидат військових наук)

Національний університет оборони Украӥни імені Івана Черняховського, Київ, Украӥна

\title{
АНАЛІЗ ПІДХОДІВ ДО ПРОГНОЗУВАННЯ ПСИХОГЕННИХ ВТРАТ ВІЙСЬК (СИЛ) В БОЙОВИХ УМОВАХ: СТРУКТУРА ЧИННИКІВ
}

В статті розглянуто основні тендениії до змін форм і способів збройної боротьби та їхнього впливу на збільшення рівня психотравмованості особового складу військ (сил).

Проаналізована низка підходів до оцінювання рівня психогенних втрат особового складу військ в бойових умовах, застосування яких оптимізує процедури захисту морально-психологічних якостей військовослужбовиів від негативного інформаційно-психологічного впливу противника. Визначено підходи до структурування чинників, які обумовлюють психогенні втрати: психофізіологічний, професійний, соиіальний, прочедурний. Наведено недоліки та позитивні сторони наведених підходів щэодо визначення статичних характеристик системи прогнозування психогенних втрат військ (сил) в бойових умовах.

Запропоновано шляхи впровадження окремих підходів до прогнозування психогенних втрат військ (сил) у діяльність системи управління Збройних Сил Украӥни з урахуванням перспектив впровадження стандартів НАТО і теоретичних поглядів вітчизняних фахівців.

Запропоновано додатково до зовнішніх чинників, щчо спричиняють психогенні втрати у визначеному для подальшого розвитку підході, віднести тривалість та інтенсивність ведення бойових дій, до внутрішніх - ступінь укомплектованості органів управління службовими особами, підготовленими до прогнозування, профілактики та надання психологічної допомоги психотравмованим; ступінь сформованості активів з контролю бойового стресу; ступінь їх матеріально - технічного забезпечення; ступінь організації та проведення заходів морально-психологічного забезпечення; ступінь організачіі заходів інформачійно - психологічного протиборства худе.

Ключові слова: захист від негативного інформаційно-психологічного впливу, прогнозування психогенних втрат психічна стійкість, психологічна готовність, структура чинників, система управління, автоматизація розрахунків.

\section{Вступ}

Результати аналізу воєнних конфліктів останніх десятиріч вказують на стійку тенденцію збільшення частки інформаційно-психологічних операцій та переходу до “гібридних" дій, які посилюють невпевненість, страх у особового складу та ускладнюють підтримання командирами та їхніми заступниками з морально-психологічного забезпечення (МПЗ) головної умови реалізації бойового потенціалу військ - “пориву до знищення ворога”, за визначенням Г. Клаузевіца.

Постановка проблеми. Аналіз бойових дій на сході України виявив недостатню увагу з боку командирів військових частин та підрозділів щодо контролю та прогнозування психогенних втрат, які можуть складати до 30\% від санітарних [1].

Аналіз останніх досліджень і публікацій. аналіз джерел [2-5,7-10,12,13] дозволяє зробити висновок, що чинники, які обумовлюють психогенні втрати військ в бойових умовах, за різними підходами мають різну структуру, зокрема виокремлюється така спрямованість формування груп чинників: психофізіологічна [2,4,5,9], професійна [3,10], соціальна [6,12], процедурна [13].

Метою статті $\epsilon$ аналіз підходів до структурування чинників, які обумовлюють психогенні втрати військ (сил) в бойових умовах.

\section{Виклад основного матеріалу дослідження}

Психогенні втрати доцільно розглядати, як втрати особового складу військ (сил), зумовлені психічними травмами та розладами від впливу стрес-чинників бойових дій.

Тимчасові психогенні втрати короткотермінова втрата боєздатності особового складу, відновлення якої досягають методом само- та взаємодопомоги безпосередньо в підрозділі у бойовій обстановці.

Щодо структури - це взаєморозміщення та взаємозв'язок складових частин цілого; відносно стійкий, впорядкований спосіб зв'язку елементів, що надає їхній взаємодії у рамках 
внутрішньо розчленованого об'єкту цілісний характер. У той же час, структура може визначати внутрішню організацію системи (процесу).

Отже, аналіз підходів до структурування стресчинників бойових дій та інших чинників, які обумовлюють психогенні втрати військ (сил), забезпечить визначення статичних характеристик системи за ії̈ структурою.

Аналіз основних тенденцій пов'язаних із змінами форм і способів бойових дій дозволяє стверджувати про згладжування відмінностей між бойовими і не бойовими формами дій; прагнення до випередження противника в темпі та інтенсивності ведення бойових дій; значного зростання точності вогневого ураження цілей, досягнення інформаційної переваги; широке використання сил і засобів інформаційної, радіоелектронної боротьби тощо, що призводить до збільшення частки психогенних втрат [11].

Найбільш розповсюдженими методами діяльності сил IПсО РФ, які спрямовані на деморалізацію особового складу залишаються [3]:

поширення в ЗМІ інформації провокаційного змісту;

підготовка i поширення в соціальних мережах та на інших ресурсах мережі Інтернет спеціальних матеріалів, спрямованих на дискредитацію керівництва України, командування та військовослужбовців сил АТО;

здійснення інформаційно-психологічного впливу на коло контактів у соціальних мережах полонених військовослужбовців ЗС України;

розсилання

СМС-повідомлень деморалізуючого змісту на номери телефонів військовослужбовців та цивільного населення;

теракти та підривна діяльність (в різних регіонах України), деморалізація керівного складу військ (сил) України агентурою РФ тощо.

В свою чергу, за загальним підходом психогенні втрати за психофізіологічними станами поділяються на безповоротні, санітарні і тимчасові.

Безповоротні психогенні втрати - втрата військовослужбовцями боєздатності, внаслідок якої стає неможливим повернення особового складу до строю взагалі. Психотравмовані військовослужбовці потребують тривалого лікування, надання медичної допомоги та професійної психологічної і психіатричної допомоги у спеціалізованих закладах, проходження курсу соціальної та психологічної реабілітації.

Санітарні психогенні втрати - втрата військовослужбовцями боєздатності, відновлення якої досягають наданням психологічної допомоги та реабілітації у відповідних пунктах надання психологічної допомоги та реабілітації.

Отже, до бойових психогенних втрат зараховують особовий склад, людей, які втратили боєздатність унаслідок дії бойових психогенних стрес-факторів на короткий або тривалий час.

Уміння грамотно прогнозувати й оцінювати рівень можливих бойових психогенних втрат дозволить своєчасно та обгрунтовано організувати систему їх запобігання, проводити заходи психологічної допомоги і відновлення боєздатності особового складу у військовій частині.

За рівнями абстрагування передусім доцільно розглянути поділ чинників, які обумовлюють психогенні втрати військ в бойових умовах на зовнішні та внутрішні.

Подібний розподіл наведено в табл. 1. [9].

У роботі [7], залежно від виду впливу на організм військовослужбовця, чинники поділяються на фізіологічні (біль, висока та низька температура тощо) та психологічні, які, в свою чергу, поділяються на емоційні (небезпека, загибель товаришів, поранення і травми, участь в знищенні ворога, висока відповідальність) та інформаційні (раптовість, новизна обстановки, недостатність або надмірність інформаціі).

Таблиця 1

Чинники, що впливають на безперервні бойові дії воїнів

\begin{tabular}{|c|l|}
\hline Чинники & \multicolumn{1}{|c|}{ Зміст чинників } \\
\hline \multirow{3}{*}{ Зовнішні } & $\begin{array}{l}\text { Умови середовища } \\
\text { діяльності) }\end{array}$ \\
\cline { 2 - 2 } & Соціальні умови \\
\hline \multirow{3}{*}{ Внутрішнінаня, } \\
\cline { 2 - 2 } & Умови професійної діяльності \\
\cline { 2 - 2 } & Інформаційні чинники \\
\cline { 2 - 2 } & Психофізіологічні чинники \\
\hline
\end{tabular}

Найбільшу деталізація та структурування чинників негативного впливу на військовослужбовців 3 урахуванням досвіду АТО та ООС має підхід [8], у якому загальними $€$ такі чинники як раптовість (обстріл, теракт, напад), тривалість (тривалість участі в активних діях, соціально-політична або фінансова криза) та інтенсивність (інтенсивність та пролонгованість стресових реакцій та їхні наслідки). Саме ці чинники визначають характер перетікання стресових реакцій глибину та тривалість фаз стресу i його наслідків. Якщо раптовість визначає наявність шоку та психофізіологічних i емоційних реакцій, то інтенсивність впливу стрес-факторів визначає глибину шоку і гостроту цих реакцій. Якщо тривалість напруження призводить до психофізіологічного та емоційного “вигорання", то інтенсивність визначає ступінь “вигорання” та можливість відновлення.

Відтак, такий чинник як інтенсивність інтегрує у часі рівень бойової активності військовослужбовців, значимість бойових дій 
для кожного 3 них, рівень напруженості і характер бойових дій, бойові втрати.

Наступна структура внутрішніх чинників впливу на МПС особового складу військ (сил) та стійкість впливу розкрита в праці [12] табл. 2 .

Таблиця 2

Внутрішні чинники, що впливають на МПС особового складу

\begin{tabular}{|c|c|}
\hline $\begin{array}{c}\text { Назва групи } \\
\text { чинників }\end{array}$ & Зміст чинників \\
\hline Особистісні & $\begin{array}{c}\text { Позитивний копінг-процесс, позитивний } \\
\text { аффект, позитивний роздум, реалізм, } \\
\text { динамічний контроль }\end{array}$ \\
\hline Родинні & Комунікація, підтримка, близькість родини, \\
виховання
\end{tabular}

\begin{tabular}{|c|c|}
\hline $\begin{array}{c}\text { Назва групи } \\
\text { чинників }\end{array}$ & Зміст чинників \\
\hline Колективні & $\begin{array}{c}\text { Позитивний командний клімат, взаємодія, } \\
\text { покращення посттравматичного стану, } \\
\text { роль, що моделює }\end{array}$ \\
\hline Суспільні & соціальна підтримка, зв’язність, загальні \\
цінності
\end{tabular}

Важливе значення для визначення чинників, які впливають на психогенні втрати військ в бойових умовах, має структура процесу, який досліджується. Тому, особливої уваги потребує системний підхід до процесу впливу зазначених чинників [13] (рис. 1), де у якості діагностичних критеріїв негативного ІПВ використовуються чотири групи чинників.

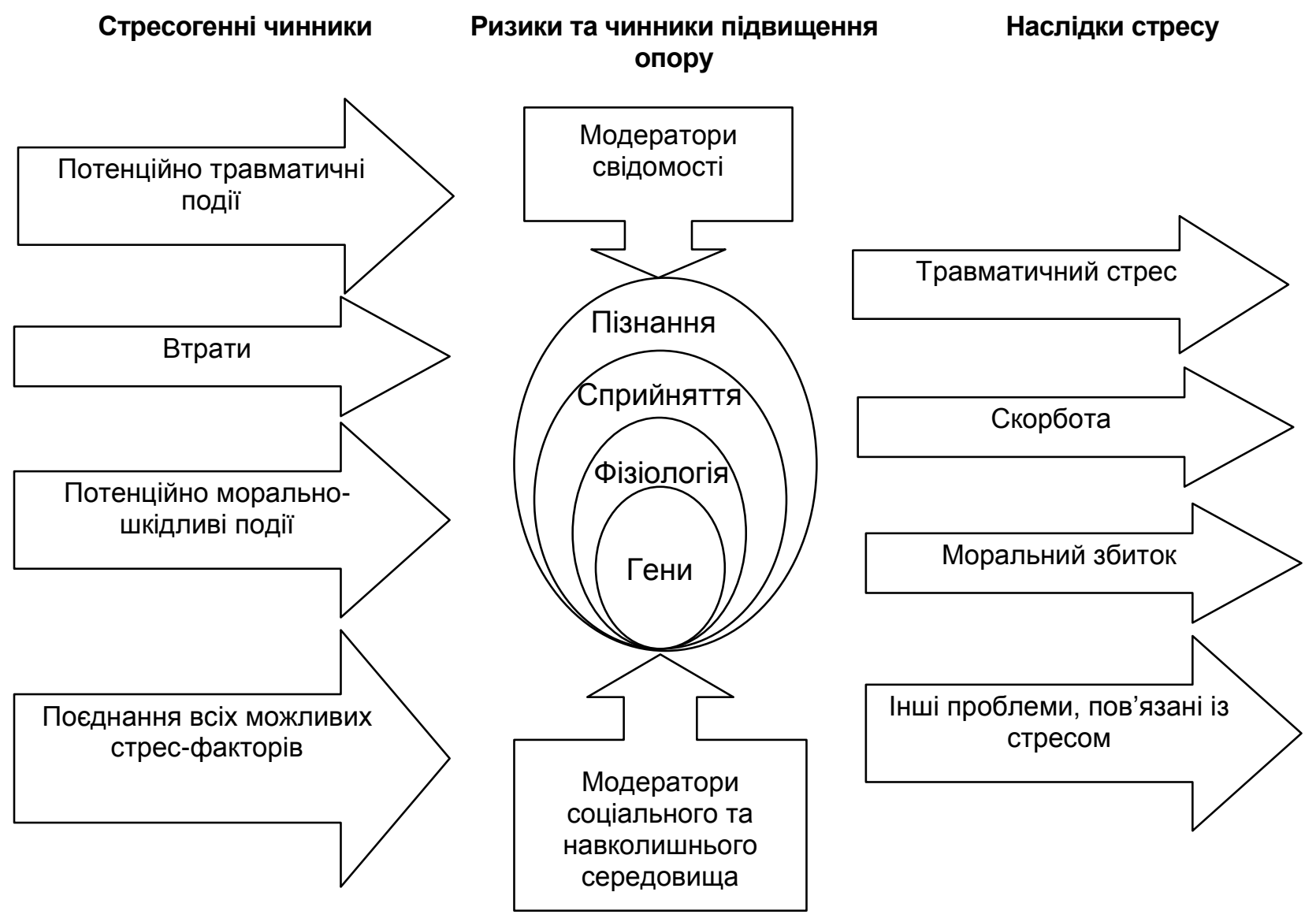

Рис. 1. Структурно-логічна схема класифікації чинників негативного інформаційно-психологічного впливу та прогнозування психогенних втрат військ [13]

Перші три узагальнюють події потенційно високої дії: перша - потенційно травматичні події, що включають смерть або іiі загрозу, серйозне ушкодження себе або інших; друга - втрати близьких людей, речей, травмування; третя потенційно морально шкідливі події. Четверта об'єднує стресори усіх типів, невпливові поодинці та $€$ інструментом тривалих операцій сил, IПсО щодо зміни мотиваційної спрямованості населення країни, зниження його психічної стійкості.
Відтак, згідно схеми, яка наведена на рис. 1 не здійснюється аналіз інтенсивності бойових дій, що має суттєвий вплив на психогенні втрати особового складу військ у бойових умовах. Таке доповнення дозволить визначати вплив інтенсивності групи потенційно травматичних події, що включає смерть або іiї загрозу, серйозне ушкодження себе або інших.

У свою чергу, для уточнення вищенаведеної структури чинників, які обумовлюють психогенні Modern Information Technologies in the Sphere of Security and Defence № 1(34)/2019ＩSSSN2311-7249(Print)/ISSSN2410-7336(Onine) 15 
втрати військ в бойових умовах може бути використано поведінковий підхід до оцінювання результатів ПсО [6], у якому використовують показники оцінювання, індикатори впливу, спонтанні події, результати пост-тестування, які наведено в табл. 3.

Інші підходи до структурування окремих чинників, які обумовлюють психогенні втрати військ (сил) в бойових умовах та уточнені за результатами бойової діяльності в умовах АТО наведено у праці [4], зокрема: прогностична модель підтримки прийняття рішення про низьку адекватність поведінки в екстремальних ситуаціях; структура стрес-чинників бойового середовища; структура стрес-чинників організації забезпечення життєдіяльності; інформаційні чинники; прояви вторгнення, ухилення, фізіологічного напруження, дезадаптації у військовослужбовців-учасників АТО; функціональні стани військовослужбовців; рівні стресостійкості військовослужбовців. В той же час, автори звертають увагу на можливість прогнозування адекватності поведінки військовослужбовців в бойових умовах тільки 3 допомогою спостереження за бойовим побратимом.

Таблиця 3

Приклад розроблення початкових показників оцінювання

\begin{tabular}{|c|c|}
\hline $\begin{array}{c}\text { Потенційна } \\
\text { цільова } \\
\text { аудитория }\end{array}$ & Показники оцінювання \\
\hline $\begin{array}{c}\text { Члени НЗФ } \\
\text { з числа } \\
\text { місцевих } \\
\text { жителів }\end{array}$ & $\begin{array}{l}\text { Скільки членів НЗФ було вбито/захоплено } \\
\text { під час } \\
\text { мінування шляхів? } \\
\text { Скільки членів НЗФ здалося урядовим } \\
\text { силам під час } \\
\text { мінування шляхів? } \\
\text { Скільки виявлено випадків навмисного } \\
\text { невиконання членами НЗФ завдань } 3 \\
\text { мінування шляхів? }\end{array}$ \\
\hline & $\begin{array}{l}\text { Скільки публічних заяв щодо протидії } \\
\text { НЗФ було зроблено } \\
\text { представниками влади? } \\
\text { Скільки громадських заходів } 3 \text { протидії } \\
\text { НЗФ проведено? }\end{array}$ \\
\hline Населення & $\begin{array}{l}\text { Скільки повідомлень про випадки } \\
\text { мінування/діяльності НЗФ надійшло по } \\
\text { телефону “гарячої лінії”? } \\
\text { Скільки особистих звернень населення } \\
\text { про випадки мінування/діяльності НЗФ } \\
\text { зареєстровано? } \\
\text { Скільки людей брало участь у у } \\
\text { громадських заходах з протидії НЗФ? } \\
\text { Скільки загонів самооборони створено та } \\
\text { діє? }\end{array}$ \\
\hline
\end{tabular}

\section{Jimepamypa}

1. Алещенко В. Проблемні питання МПЗ застосування військ (сил) в ході АТО / Особливості підготовки і застосування військ (сил) ЗСУ в АТО на Сході України: наук. - практ. сем., 24 лист.2015 р.:тези доп. К.:НУОУ,
На підставі проведеного аналізу різноманітних сукупностей чинників, які обумовлюють психогенні втрати військ в бойових умовах доцільно підкреслити значну практичну (процедурну) спрямованість для інформаційного моделювання структури чинників, які обумовлюють психогенні втрати військ в бойових умовах ( W.Nash) [13].

\section{Висновки і перспективи подальших досліджень}

Таким чином, запропонована структура чинників широко розкриває процес організації протидії негативному ІПВ противника, зокрема: за ієрархію вибудовує основні групи стрес-чинників, визначає низку взаємозв'язаних цілей щодо успішного виконання бойового завдання та збереження морально-бойових якостей особового складу; визначає елементи організаційної структури за родинним, колективним та суспільним рівнями, що реалізовують сформовані цілі; виключення елементів, що не мають мети функціонування; виявлення завдань організації МПЗ, які потрібні для ефективної реалізації усіх його фаз (етапів); зіставлення виділених функцій елементам (виконавцям, керівникам, органам, технічним пристроям) аналізованої системи i оцінка повноти їхньої реалізації; виявлення дублюючих, малоефективних, зайвих функцій i розроблення рекомендацій 3 вдосконалення системи управління МПЗ.

Водночас, до зовнішніх чинників, які обумовлюють психогенні втрати військ (сил) в бойових умовах, доцільно віднести тривалість та інтенсивність ведення бойових дій, до внутрішніх ступінь укомплектованості органів управління службовими особами, підготовленими до організації та здійснення інформаційно-психологічного протиборства; ступінь сформованості психологічних активів в підрозділах; ступінь матеріальнотехнічного забезпечення організації та проведення заходів МПЗ; ступінь методичного забезпечення організації заходів інформаційно-психологічного протиборства.

У подальшому пропонується проводити дослідження в напрямі удосконалення методичних підходів до прогнозування психогенних втрат військ (сил) в бойових умовах відповідно до процедур що прийняті в ЗС країн НАТО.

2015. С. 30-34. 2. Блінов О. Психологія бойової психічної травми. Київ, 2016. 180 с. 3. Бочаров М., Приймак М. Досвід використання методик оцінювання негативного інформаційно-психологічного впливу в 16 ISSN2311-7249(Print)/ISSN2410-7336(Onfine) Сучасні інббормахійні технологіїу собері безпеки та оборони № 1 (34)/2019 
прогнозуванні морально-психологічного стану військ у бойових умовах // Сучасні інформаційні технології у сфері безпеки та оборони. Київ : НУОУ, 2016. № 1 (25). С. 15-19. 4. Гічун В., Кириченко А., Корнацький В., Мясников Г., Н Найда С., Осьодло В., Стеблюк В., Швець А. Стрес-асоційовані розлади здоров'я в умовах збройного конфлікту : монографія. Дніпро: 2019. 324 с. 5. Екстремальна психологія / О. Тімченко та інші. Київ, 2007. 502 с. 6. Замичковський В., Тарасов С., Цурко Ю. аналіз існуючих методичних підходів до оцінювання ефективності заходів психологічного впливу у військових конфліктах сучасності // Збірник науксших праць ЦНДІ ЗС України № 1 (83) 2018. С.137144. 7. Караяни А., Сыромятников И. Прикладная военная психология. Санкт-Петербург, 2006. 480 с. 8. Літвінов А. Яким буває стрес і що впливає на його протікання та наслідки. URL : http://psyhelp.beyourself.com.ua/stres-iptsr/psixologicheskaya-pomoshh-pri-ptsr/vipusk-7 (дата звернення: 09.01.2016). 9. Романишин А., Бойко О., Гузенко I. Первинна психологічна допомога i реабілітація в бойових умовах. Львів, 2014. 140 с. 10. Стасюк В., Павловський О., Замичковський В. Аналіз підходів до оцінювання моральнопсихологічного стану особового складу військ (сил) // Труди університету Вип. 2 (141). К.: НУОУ. 2017. С. 222-228. 11. Федоренко В. Розвиток тактики за досвідом локальних війн кінця XX - початку XXI століть. URL : irbis-nbuv.gov.ua (дата звернення: 10.01.2014). 12. Meredith L., Sherbourne C. Promoting psychological resilience in the U.S. URL http://www.rand.org/publications/permissions. (дата звернення: 03.04.2014). 13. Nash W. Model spacious of battle and operative stress of Corps of Marines and Military - Marine Forces of the USA: instrument for leaders // Combat and operational behavioral health office. 2011. C.185-189.

\title{
АНАЛИЗ ПОДХОДОВ К ПРОГНОЗИРОВАНИЮ ПСИХОГЕННЫХ ПОТЕРЬ ВОЙСК (СИЛ) В БОЕВЫХ УСЛОВИЯХ: СТРУКТУРА ФАКТОРОВ
}

\author{
Василий Васильевич Стасюк (доктор психологических наук, профессор) \\ Михаил Николаевцч Бочаров (кандидат военных наук)
}

\section{Национальный университет обороны Украины имени Ивана Черняховского, Киев, Украина}

В статье рассмотрены основные тенденции к изменениям форм и способов вооруженной борьбы и их влияния на увеличение уровня психотравмирования личного состава войск (сил).

Проанализированный ряд подходов к оцениванию уровня психогенных потерь личного состава войск в боевых условиях, применение которых оптимизирует процедуры защчиты моральнопсихологических качеств военнослужащих от негативного информаџионно-психологического влияния противника. Определены подходы к структуризации факторов, которые обусловливают психогенные потери: психофизиологический, профессиональный, сочиальный, процедурный. Приведень недостатки и позитивные стороны розкритых подходов относительно определения статичных характеристик системы прогнозирования психогенных потерь войск (сил) в боевых условиях.

Предложены пути внедрения отдельных подходов к прогнозированию психогенных потерь войск (сил) в деятельность системы управления Вооруженных Сил Украины с учетом перспектив внедрения стандартов НАТО и теоретических взглядов отечественных специалистов.

Предложено дополнительно к внешним факторам, которые вызывают психогенные потери в определенном для дальнейшего развития подходе, отнести длительность и интенсивность ведения боевых действий, к внутренним - степень укомплектованности органов управления служебными лицами, подготовленными к прогнозированию, профилактике и предоставлению психологической помощи психотравмированным; степень сформированности активов для контроля боевого стресса; степень их материально-технического обеспечения; степень организачии и проведения мероприятий морально-психологического обеспечения; степень организации мероприятий информационнопсихологического противоборства и тому подобное.

Ключевые слова: защита от негативного информационно-психологического влияния, прогнозирование психогенных потерь психическая стойкость, психологическая готовность, структура факторов, система управления, автоматизаџия расчетов.

\section{ANALYSIS OF GOING NEAR PROGNOSTICATION OF PSYCHOGENIC LOSSES OF TROOPS IN BATTLE CONDITIONS: STRUCTURE OF FACTORS}

\author{
Vasyl Stasiuk (Doctor of psychological sciences, professor) \\ Mykhailo Bocharov (Candidate of military sciences)
}

National Defence University of Ukraine named after Ivan Cherniakhovsky, Kyiv, Ukraine 
The article is devoted to the main tendencies oa changes in the forms and methods of combat activity and their influence on the increasing level of psychological trauma of the personnel of the forces (troops).

The article analyzes a number of approaches to assessing the level of psychogenic losses of troops in combat circumstance. The application of these approaches optimizes the procedures for protecting the moral and psychological qualities of servicemen from the negative informational and psychological impact of the enemy.

Were identified approaches to the structuring of factors that predetermine psychogenic loss: psychophysiological, professional, social, procedural.

The advantages and disadvantages of these approaches are identified to determine the static characteristics of the system of prediction of psychogenic losses of troops (forces) in combat circumstance.

The ways of implementation of separate approaches to prediction of psychogenic losses of troops (forces) in the activity of the Armed Forces management system of Ukraine are proposed, taking into account the prospects of implementation of NATO standards and the theoretical views of domestic experts.

It is suggested to further include the duration and intensity of the conduct of hostilities to external factors that cause psychogenic losses in a particular approach. The internal ones include the level of staffing of the bodies of management of the officials prepared for the forecasting, prevention and provision of psychological assistance to the psychologically traumatized; the level of formation of assets for control of combat stress; the level of their logistical support; the level of organization and implementation of moral and psychological support; the level of organization of events information and psychological combat, etc.

Key words: protection from negative informational and psychological influence, negative informational and psychological influence, prediction of psychogenic losses, psychological stability, psychological readiness, factor structure, control system, automation of calculations.

\section{References}

1. Aleshchenko V. Problem questions of MPS of application of troops (forces) during ATO / of Feature of preparation and application of troops (forces) of $3 \mathrm{CY}$ in ATO on East of Ukraine : sciences. - pract. sem., 24 sheets.2015 p.:art. sp.. K.:NDU, 2015. P. 30-34. 2. Blinoff O. Psychology of battle psychical trauma. Kyiv, 2016. 180 c. 3. Bocharoff M., Prumak M. Experience of the use of methodologies of evaluation of negative informatively-psychological influence in prognostication of the morally-psychological state of troops in battle conditions // Modern information technologies in the field of safety and defensive. Kyiv: NDU, 2016. № 1 (25). C. 15-19. 4. Gigchun V., Kirichenko A., Kornanitski V., Miasnikoff G., Foundling S., Osiodlo V., Stebliuk V., Bootmaker A. Stress-assosiated disorders of health in the conditions of the armed conflict: monograph. Dnepr: 2019. 324 c. 5. Extreme psychology / of O. Timchenko and other. Kyiv, 2007. 502 c. 6. Zamychkovsky V., Tarasoff S., Tsurko J. analysis of the existent methodical going near the evaluation of efficiency of measures of psychological influence in the soldiery conflicts of contemporaneity // Collection of science labours of CSI AF Ukraine № 1 (83) 2018. C.137-144. 7. Karaiani A., Syromiatnikoff I.
Militari psihological handbook. S. Petersburg, 2006. 480 c. 8. Litvinoff A. What stress is and that influences on his flowing and consequences. URL: http://psyhelp.beyourself.com.ua/stres-i-

ptsr/psixologicheskaya-pomoshh-pri-ptsr/vipusk- 7 (date of appeal : 09.01.2016). 9. Romanishin A., Boyko O., Guzenko I. A primary psychological support and rehabilitation are in battle conditions. Lviv, 2014. 140 c. 10. Stasiuk V., Pavlovsky O., Zamichkovsky V. Analysis of going near the evaluation of the moral-psychological state of personnel of troops (forces) // Labours of university of Edit. 2 (141). K.: NDU. 2017. C. 222-228. 11. Fedorenko V. Development of tactic/pl after experience of local wars of end of XX - to beginning of XXI of centuries. URL: irbis - nbuv.gov.ua (date of appeal : 10.01.2014). 12. Meredith L., Sherbourne C. Promoting of psychological resilience in the of U.S. URL: http://www.rand.org/publications/ permissions. (date of appeal : 03.04.2014). 13. Nash W. Model of spacious of battle and operative stress of of Corps of of of Marines of and of Military - Marine Forces of the of USA : instrument for leaders // of Combat of and operational behavioral health office. 2011. C.185-189. 